\title{
Antibiotic resistance patterns of pediatric Typhoid fever at the Department of Child Health, Hasan Sadikin General Hospital, Bandung
}

Djatnika Setiabudi, M.S. Azhali, Herry Garna, Alex Chairulfatah

\begin{abstract}
Abstrak
Kami meninjau kembali kasus-kasus demam tifoid terkonfirmasi secara bakteriologik yang dirawat di bagian kami sejak I Juli 1994 sampai 30 Juni 1997. Ada 50 kasus yang dievaluasi pola resistensi antibiotikanya. Biakan darah dilakukan dengan metoda difusi Kirby-Bauer: Penentuan sensitivitas dilakukan dengan kriteria dari The National Committee for Clinical Laboratory Standards (NCCLS). Hasil uji sensitivitas menunjukkan bahwa 85,4\% (41/48) sensitif terhadap kloramfenikol; 88,8\% (40/45) terhadap ampisilin; 91,6\% (22/24) terhadap amoksisilin; 83,65\% (41/49) terhadap kotrimoksazol; dan 96,0\% (48/50) terhadap siprofloksasin. Jumlah isolat yang resisten terhadap antibiotik tersebut di atas berturut turut $10,4 \%, 6,6 \%, 8,4 \%, 10,2 \%$ dan 4,0\%. Hasil sisanya adalah intermediate. Tiga isolat Salmonella typhi resisten terhadap tiga antibiotika (kloramfenikol, ampisilin dan kotrimoksazol). Berdasarkan antibiotika yang diberikan pertama kali pada penderita, tidak ada sinkronisasi antara sensitivitas in vitro dengan respons klinis pada $10(20 \%)$ penderita.
\end{abstract}

\begin{abstract}
We reviewed bacteriologically confirmed typhoid fever patients, hospitalized in our department from July 1, 1994 to June $30,1997$. There were 50 cases who were evaluated for antibiotic resistance patterns. Blood culture was carried out using Kirby-Bauer diffusion method. The determination of bacteriological sensitivity was carried out using criteria established by The National Committee for Clinical Laboratory Standards (NCCLS). Result of sensitivity test showed that $85.4 \%$ (41/48) were sensitive to chloramphenicol; $88.8 \%$ (40/45) to ampicillin; $91.6 \%(22 / 24)$ to amoxycillin; $83.65 \%$ (41/49) to co-trimoxazole, and $96.0 \%$ (48/50) to ciprofloxacin. Number of isolates which resistant to these antibiotics were $10.4 \%, 6.6 \%, 8.4 \%, 10.2 \%$ and $4.0 \%$, respectively. The other results were intermediate. Three isolates of Salmonella typhi were resistant to three antibiotics (chloramphenicol, ampicillin and co-trimoxazole). According to antibiotics which administered firstly to the patients, there was no apparent synchronization between in vitro sensitivity with in vivo clinical response in $10(20 \%)$ patients.
\end{abstract}

Department of Child Health, Faculty of Medicine, Padjadjaran University, Bandung, Indonesia. 